\title{
PEMBELAJARAN ASYIK DAN MENYENANGKAN MELALUI MENDONGENG DI SD IBA PALEMBANG
}

\author{
Tresiana Sari Diah Utami ${ }^{1}$, Billy Suandito ${ }^{2}$, Katarina Retno Triwidayati ${ }^{3}$, Sukarman $^{4}$ \\ Program Studi Pendidikan Guru Sekolah Dasar Universitas Katolik Musi Charitas Palembang \\ Email: tresiana@ukmc.ac.id ${ }^{1}$, billy_s@ukmc.ac.id ${ }^{2}$ retno@ukmc.ac.id ${ }^{3}$, sukarman@ukm.ac.id ${ }^{4}$
}

\begin{abstract}
Abstrak
Target dan luaran dalam kegiatan ini adalah mengenalkan siswa-siswa kelas 1 SD IBA Palembang pembelajaran melalui mendongeng. Pembelajaran melalui mendongeng merupakan pembelajaran yang bersifat menyenangkan.Dalam rangka mengelola proses pembelajaran, mendongeng menjadi salah satu metode yang dapat dipilih. Melalui mendongeng, materi pembelajaran diberikan melalui kegiatan bercerita. Sehingga pesan moral yang ingin disampaikan dapat dikemas dan diharapkan dapat diserap oleh peserta didik terutama peserta didik di kelas rendah.Metode yang digunakan dalam kegiatan pengabdian di SD IBA Palembang metode simulasi, discovery, dan tanya jawab. Harapannya, seluruh siswa mendapatkan pengajaran menarik melalui mendongeng.
\end{abstract}

\section{Kata Kunci: Pengajaran, Mendongeng, SD IBA Palembang}

\begin{abstract}
The target and outcome in this activity is to introduce grade 1 students of SD IBA Palembang to learn through storytelling. Learning through storytelling is fun learning. In order to manage the learning process, storytelling is one method that can be chosen. Through storytelling, learning material is provided through storytelling. So that the moral message to be conveyed can be packaged and is expected to be absorbed by students, especially students in the low class. The method used in the service activities at SD IBA Palembang is a simulation, discovery, and question and answer method. The hope, all students get interesting teaching through storytelling.
\end{abstract}

\section{Keywords: Teaching, Storytelling, SD IBA Palembang}

\section{Pendahuluan}

Kegiatan pembelajaran di sekolah menjadi kegiatan yang membutuhkan proses yang panjang. Dalam pelaksanaannya, kegiatan pembelajaran dimungkinkan mengakibatkan kebosanan. Selain kebosanan, proses pembelajaran yang panjang memungkinkan inti materi tidak sampai secara utuh kepada peserta didik.

Dalam rangka mengelola proses pembelajaran, mendongeng menjadi salah satu metode yang dapat dipilih. Melalui mendongeng, materi pembelajaran diberikan melalui kegiatan bercerita. Sehingga pesan moral yang ingin disampaikan dapat dikemas dan diharapkan dapat diserap oleh peserta didik terutama peserta didik di kelas rendah.

Kegiatan mendongeng juga sejalan dengan program pemerintah yaitu Indonesia Mendongeng. Kegiatan ini mengajak para orang tua dan pengajar untuk berkomunikasi dengan anak salah satunya dengan mendongeng. Kegiatan mendongeng dianggap positif karena menjalin komunikasi dengan anak, meningkatkan imajinasi anak, dan kedekatan emosional antara anak dan orang tua/pengajar. 
Berdasarkan uraian di atas, kami memandang perlunya kegiatan mendongeng di sekolah melalui kegiatan pengabdian pada masyarakat. Kegiatan ini dilaksanakan di SD IBA Palembang.

Berdasarkan uraian analisis situasi di atas, sekolah mitra dalam hal ini Sekolah Dasar IBA Palembang belum mendapatkan pengajaran melalui mendongeng. Dengan demikian rumusan operasional permasalahan mitra sebagai berikut.

1. Bagaimana pengemasan materi pembelajaran yang disampaikan melalui mendongeng?

2. Bagaimana hasil pengajaran melalui mendongeng?

Tujuan kegiatan ini adalah penyampaian materi kepada siswa SD Kelas I di SD IBA Palembang melaui kegiatan mendongeng. Luaran dalam kegiatan ini adalah siswa SD Kelas I di SD IBA Palembang. Adapun luaran yang dihasilkan dalam program pengabdian masyarakat ini adalah berupa kegiatan mendongeng. Siswa memiliki pengetahuan berupa kegemaran yang disampaikan melalui mendongeng.

\section{Bahan dan Metode Pelaksanaan}

Kegiatan ini berupa kegiatan pengajaran untuk siswa SD Kelas I di SD IBA Palembang. Setelah diberikan pendampingan. Berikut ini adalah tahapan pendampingan yang dilakukan.

\begin{tabular}{|c|c|c|}
\hline $\begin{array}{c}\text { Hari/ } \\
\text { Tanggal }\end{array}$ & Waktu & RincianKegiatan \\
\hline $\begin{array}{l}\text { Senin/ } \\
6 \text { Maret }\end{array}$ & & 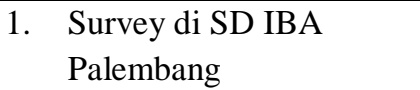 \\
\hline $\begin{array}{l}2017 \\
\text { Kamis- } \\
\text { Jumat/ } \\
9-10 \\
\text { Maret } \\
2017\end{array}$ & 1 jam & $\begin{array}{l}\text { Kegiatan survey menjadi } \\
\text { kegiatan pencarian data } \\
\text { untuk menunjang kegiatan } \\
\text { mendongeng yang akan } \\
\text { dilaksanakan. Data yang } \\
\text { dimaksud adalah data } \\
\text { tentang } \\
\text { 1) jumlah siswa, }\end{array}$ \\
\hline
\end{tabular}

\begin{tabular}{|c|c|c|}
\hline $\begin{array}{c}\text { Hari/ } \\
\text { Tanggal }\end{array}$ & Waktu & RincianKegiatan \\
\hline & 4 jam & $\begin{array}{l}\text { 2) kondisi kelas, } \\
\text { 3) latar belakang siswa, } \\
\text { 4) kegiatan pembelajaran } \\
\text { yang selama ini } \\
\text { dilakukan. } \\
\text { 2. Analisa hasil survey } \\
\text { Kegiatan analisa hasil } \\
\text { survey ini dilakukan untuk } \\
\text { mendukung kegiatan } \\
\text { persiapan. }\end{array}$ \\
\hline $\begin{array}{l}\text { Sabtu- } \\
\text { Kamis/ } \\
11-16 \\
\text { Maret } \\
2017\end{array}$ & $10 \mathrm{jam}$ & $\begin{array}{l}\text { Persiapan } \\
\text { Kegiatan persiapan meliputi, } \\
\text { 1. Analisa materi dongeng } \\
\text { Kompetensi Inti dan } \\
\text { Kompetensi Dasar } \\
\text { Kurikulum } \\
\text { Materidongeng dianalisa } \\
\text { perwatakannya, latar, dan } \\
\text { alurnya supaya sesuai } \\
\text { dengan tahapan } \\
\text { perkembangan belajar } \\
\text { peserta didik. } \\
\text { 2. persiapan media untuk } \\
\text { mendongeng, media } \\
\text { pembelajaran merupakan } \\
\text { alat bantu penyampaian } \\
\text { materi pembelajaran yang } \\
\text { telah dipilih. Media } \\
\text { mendongeng yang } \\
\text { digunakan dapat berupa } \\
\text { boneka tangan ataupun } \\
\text { wayang sesua dengan } \\
\text { dongeng yang dipilih. } \\
\text { 3. persiapan media apresiasi } \\
\text { kepada peserta didik, } \\
\text { media apresiasi kepada } \\
\text { peserta didik digunakan } \\
\text { untuk mengapresiasi } \\
\text { peserta didik yang secara } \\
\text { aktif terlibat dalam } \\
\text { kegiatan pembelajaran. } \\
\text { Media yang digunakan } \\
\text { berupa kartu prestasi dan } \\
\text { alat tulis. }\end{array}$ \\
\hline
\end{tabular}




\begin{tabular}{|c|c|c|}
\hline $\begin{array}{c}\text { Hari/ } \\
\text { Tanggal }\end{array}$ & Waktu & RincianKegiatan \\
\hline $\begin{array}{l}\text { Jumat, } \\
24-25 \\
\text { Maret } \\
2017\end{array}$ & $\begin{array}{l}2 \text { jam } \\
3 \text { jam }\end{array}$ & 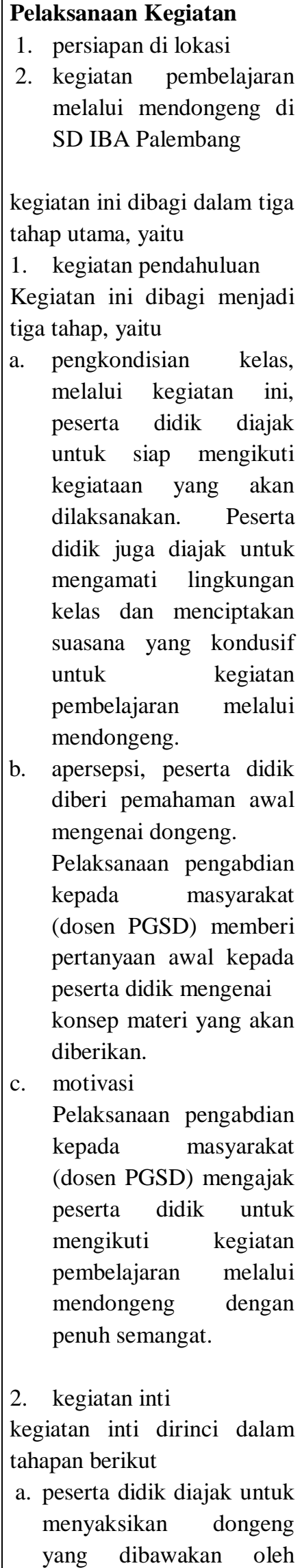 \\
\hline
\end{tabular}

\begin{tabular}{|c|c|c|}
\hline $\begin{array}{c}\text { Hari/ } \\
\text { Tanggal }\end{array}$ & Waktu & RincianKegiatan \\
\hline & & $\begin{array}{l}\text { narasumber, } \\
\text { b. pelaksanaan pengabdian } \\
\text { (dosen PGSD) } \\
\text { memberikan berbagai } \\
\text { pertanyaan kepada peserta } \\
\text { didik dalam rangka } \\
\text { menggali pemahaman } \\
\text { terhadap materi yang } \\
\text { telah disajikan melalui } \\
\text { dongeng oleh narasumber. } \\
\text { 3.kegiatan penutup } \\
\text { kegiatan penutup, dibagi } \\
\text { menjadi dua tahap yaitu } \\
\text { a.evaluasi, } \\
\text { b.refleksi. }\end{array}$ \\
\hline $\begin{array}{l}\text { Rabu, } \\
29 \\
\text { Maret } \\
2017\end{array}$ & 5 jam & $\begin{array}{llr}\text { Evaluasi } & \text { kegiatan } & \text { dan } \\
\text { penulisan } & \text { hasil } & \text { kegiatan } \\
\text { (pelaporan) } & & \end{array}$ \\
\hline
\end{tabular}

Untuk melaksanakan kegiatan tersebut digunakan beberapa metode pelatihan, yaitu:

a. Metode simulasi

Siswa langsung mendapatkan pengajaran melalui mendongeng.

b. Metode discovery

Metode discovery, di mana siswa dilatih untuk menemukan sendiri soal-soal yang berkaitan dengan kegiatan pembelajaran.

c. Metode tanya jawab

Setelah siswa mendapatkan pengajaran melalui mendongeng, siswa dan guru melakukan tanya jawab tentang isi dongeng.

Selama kegiatan pengajaran ini berlangsung, pihak mitra yaitu SD IBA Palembang menyediakan tempat dan mempersiapkan siswa yang akan mendapatkan pengajaran di aula sekolah.

Kegiatan pengabdian masyarakat yang dilakukan ini secara teknis melibatkan kerjasama antara Unika Musi Charitas Palembang dalam hal ini Fakultas Bisnis dan Akuntansi, Program Studi Pendidikan Guru Sekolah Dasar sebagai pelakunya dan 
pihak SD IBA Palembang yaitu seluruh siswa SD Kelas I di SD IBA Palembang selaku mitra kerjasama.

Keberadaan Program studi Pendidikan Guru Sekolah Dasar didukung oleh sumber daya manusia yang bermutu dan profesional sesuai dengan bidangnya, serta sarana dan prasarana yang memadai. Tim yang ditugaskan antara lain:

\begin{tabular}{|l|l|l|l|}
\hline No & \multicolumn{1}{|c|}{ Nama } & \multicolumn{1}{|c|}{ NIDN } & \multicolumn{1}{|c|}{$\begin{array}{c}\text { Bidang } \\
\text { Keahlian }\end{array}$} \\
\hline 1. & $\begin{array}{l}\text { Tresiana Sari } \\
\text { Diah U., } \\
\text { M.Pd. }\end{array}$ & 0201118803 & $\begin{array}{l}\text { Bahasa } \\
\text { Indonesia }\end{array}$ \\
\hline 2. & $\begin{array}{l}\text { Ir. Billy } \\
\text { Suandito, } \\
\text { S.Si., M.Pd. }\end{array}$ & 0212065803 & Matematika \\
\hline 3. & $\begin{array}{l}\text { Katarina } \\
\text { RetnoT., } \\
\text { M.Pd. }\end{array}$ & 0230038301 & $\begin{array}{l}\text { Bahasa } \\
\text { Indonesia }\end{array}$ \\
\hline 4. & $\begin{array}{l}\text { Sukarman, } \\
\text { S.Ag., M.Pd. }\end{array}$ & & $\begin{array}{l}\text { Psikologi } \\
\text { Anak }\end{array}$ \\
\hline 5. & $\begin{array}{l}\text { Slamet } \\
\text { Nugroho, S.S. }\end{array}$ & & Mendongeng \\
\hline
\end{tabular}

Sedangkan potensi yang dimiliki oleh siswa SD Kelas I di SD IBA Palembang adalah kemauan dan kemampuan yang kuat untuk mendapatkan pengajaran melalui mendongeng.

\section{Hasil dan Pembahasan \\ Teknis Kegiatan}

Dalam pengabdian mendongeng ini, rencana awal peserta pelatihan adalah siswa kelas 1 SD IBA Palembang. Peserta kegiatan merupakan siswa kelas $1 \mathrm{~A}, 1 \mathrm{~B}$, dan $1 \mathrm{C}$ yang berjumlah 120 siswa. Selain itu, terdapat 3 guru pendamping yang menemani mereka.

Materi mendongeng tidak ditentukan oleh pihak sekolah. Materi dongeng adalah cerita anak yang memiliki pesan berharga yang bisa diingat dan berguna bagi anak. Pelatihan mendongeng ini berjudul Jack dan Kacang Ajaib.

Kegiatan dimulai dengan pembukaan yang dibuka oleh Wakil Kepala SD IBA, Ibu
Hollyami, S.Pd. dan perkenalan tim UKMC. Setelah perkenalan sekilas, kegiatan mendongeng yang dipimpin Kak Inug pun dimulai. Kegiatan diakhiri dengan Tanya jawab sederhana secara lisan, pemberian kenang-kenangan dari UKMC kepada Kepala SD IBA.

\begin{tabular}{|l|l|l|}
\hline \multicolumn{1}{|c|}{ Waktu } & \multicolumn{1}{|c|}{ Kegiatan } & Narasumber \\
\hline $07.30-$ & Persiapan & Tim dan Guru \\
\hline $\begin{array}{l}08.00 \text { WIB } \\
08.30 \text { WIB }\end{array}$ & Pembukaan & Waka SD IBA \\
\hline $08.31-$ & Mendongeng & KakInug \\
09.00 WIB & dengan Kak Inug & \\
\hline $09.01-$ & Tanya jawab dan & Tim Dosen \\
10.00 WIB & penutupan & \\
\hline $10.01-$ & Pemberian plakat & Tim dosen dan \\
11.00 WIB & dan sarasehan & guru SD IBA. \\
& dengan guru SD & \\
& IBA & \\
\hline
\end{tabular}

\section{Hasil Pelaksanaan Kegiatan}

Pelatihan mendongeng kali ini merupakan pelatihan mendongeng yang dilakukan tim PGSD yang kedua kalinya. Dalam pelatihan, mendongeng kali ini tidak

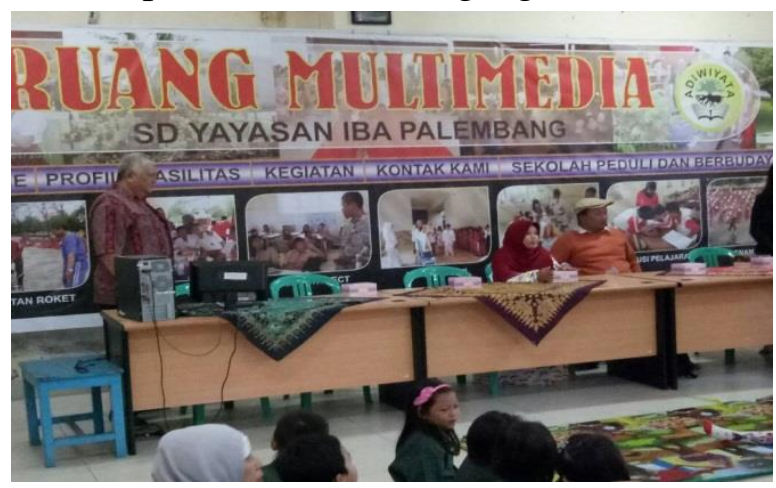
terlalu jauh berbeda dengan pelatihan mendongeng sebelumnya. Pembedanya hanya pemilihan tema atau topik cerita dongeng yang didongengkan. Sebelumnya, tema dan topik mendongeng disesuaikan dengan tema pembelajaran sedangkan topik mendongeng di SD IBA tidak ditentukan dan menggunakan cerita dongeng yang syarat akan makna untuk peserta didik.

SD IBA dipilih karena SD IBA merupakan salah satu SD yang memiliki 
popularitas baik dan menjadi salah satu SD favorit di Palembang. Hal ini bisa dilihat dengan jumlah siswa dalam tiap tingkatan yang selalu menyentuh angka 100 peserta didik bahkan lebih.Selainjuga, karena lokasi SD IBA yang tidak terlalu jauh dari Universitas Katolik Musi Charitas Palembang.

Tim melakukan penjajakan dengan cara mewawancarai narasumber yaitu Kepala SD IBA, Pak Paidi. Pak Paidi merespon baik kerjasama yang dilakukan pihak luar dengan SD IBA. Selain itu, pelatihan yang akan dilaksanakan juga bermanfaat bagi anak-anak dan juga guru kelas.

Rencana awal, pelatihan mendongeng dilaksanakan pada tanggal 22 Maret 2017, karena Kak Inug memiliki kesibukan di luar kota sehinggga tidak bisa dilaksanakan. Akhirnya pada tanggal 5 April 2017 pelatihan dilaksanakan.

Tim dosen PGSD berangkat dari Universitas Katolik Musi Charitas pukul 07.30 WIB dan sampai di IBA pukul 07.40 WIB. Sesampainya di IBA, tim dosen disambut langsung oleh Kepala SD IBA, Pak Paidi. Namun, karena persiapan ruangan yang belum fix akhirnya tim dosen menunggu di ruangan yang telah disediakan.

Tim dosendan guru diarahkan menuju ke aula IBA yang berada di lantai 2 gedung. Setiba di sana, tim dosen disambut dengan suka cita oleh anak-anak SD kelas 1. Kegiatan dimulai dengan pembukaan dan perkenalan yang dipimpin oleh Ibu Hollyami.

Memasuki kegiatan inti, Kak Inug yang bertugas untuk mendongeng membuat ruang aula menjadi lebih interaktif. Kak Inug membawakan cerita yang berjudul Jack dan Kacang Ajaib. Kak Inug menceritakan cerita tersebut dengan media boneka tangan. Ternyata, beberapa anak sudah mengetahui alur ceritanya sehingga beberapa di antara mereka ikut menceritakan juga. Namun, karena keahlian dan jam terbang Kak Inug sudah lama, ia pun bisa menangani hal tersebut.
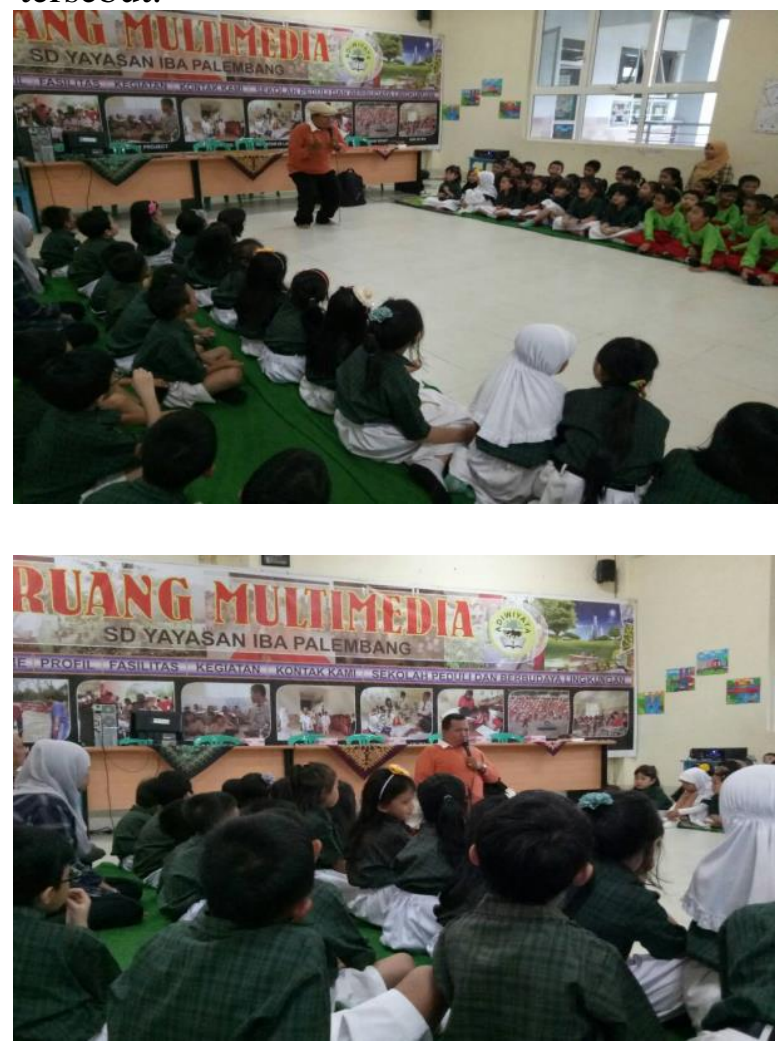

Kegiatan kemudian ditutup langsung oleh Ibu Hollyami. Namun, karenaKepala SD IBA tidak berada di ruangan, tim dosen dipersilakan menunggu di ruang kepala sekolah. Ternyata setelah dikonfirmasi, kepala sekolah sedang menghadiri undangan rapat di Diknas Kota Palembang. Kenangkenangan dan foto bersama diwakilkan oleh Ibu Hollyami.

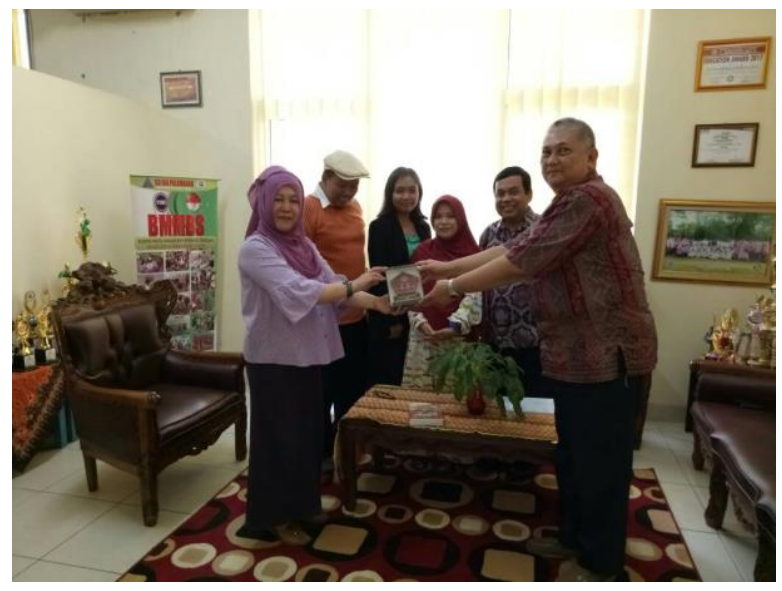


Perencanaan merupakan hal yang perlu dipersiapkan dalam proses belajar mengajar. Perencanaan yang dilakukan meliputi perangkat pembelajaran, metode. Hingga media pembelajaran.

Media dongeng dapat digunakan oleh guru ketika mereka mengajar. Media dongeng mampu menyalurkan materi pembelajaran tanpa harus menggurui. Melalui media mendongeng, guru dan siswa sebagai peserta didik merasa lebih nyaman dan santai dalam mendapatkan pengetahuan.

Tarigan (2011:79-80) mengutarakan bahwa terdapat 14 perkembangan sastra pada anak usia 6-7 tahun. Salah satunya, anakanak mulai mengembangkan empati dan memahami orang lain, anak-anak mengalami pertumbuhan rasa keadilan, menuntun aplikasi dari kaidah-kaidah atau peraturan, dan memiliki rasa humor. Hal ini sesuai dengan aplikasi dari pembelajaran melalui mendongeng bahwa pembelajaran syarat makna, memiliki rasa humor, dan mampu menjadi contoh untuk diri sendiri dari makna cerita tersbut.

Selain itu, mendongeng mampu memberikan hiburan karena terdapat humor. Sehingga guru dapat memaksimalkan pesan yang terkandung dalam sebuah cerita.

\section{Simpulan}

Berdasarkan pelaksanaan kegiatan pengajaran mendongeng yang telah dilaksanakan dapat disimpulkan bahwa,
a. Kegiatan
pengajaran
melalui
mendongeng bagi siswa kelas 1 dapat membantu siswa memahami pembelajaran.
b. Kegiatan pengajaran melalui mendongeng bagi siswa SD kelas 1 membuat siswa merasa nyaman dan

santai dalam melaksanakan proses belajar mengajar.

\section{Daftar Pustaka}

Tarigan, H. G. (2011). Dasar-Dasar Psikosastra. Bandung: Angakasa Grup. 